\title{
MEMBUMIKAN DYNAMIC GOVERNANCE DALAM MENINGKATKAN PROFESIONALISME MANAJEMEN PENYELENGGARAAN HAJI
}

\author{
Bayu Mitra Adhyatma Kusuma \\ Universitas Islam Negeri (UIN) Sunan Kalijaga Yogyakarta, bayumitraa.kusuma@yahoo.com
}

\begin{abstract}
Abstrak
Tujuan dari penelitian ini adalah untuk memberikan sumbangsih inisiatif pemikiran dalam meningkatkan profesionalisme manajemen penyelenggaraan haji melalui dynamic governance. Penelitian ini menggunakan jenis penelitian kualitatif dengan pendekatan deskriptif. Hasil penelitian dengan memperhatikan pada budaya dan kapabilitas Kementerian Agama menunjukkan bahwa thinking ahead dapat dijalankan dengan menganalisis dan memproyeksikan apa yang akan dihadapi dalam 10 atau 20 tahun ke depan berdasarkan kecenderungan perubahan nasional dan global, konstelasi politik, dan sosioekonomi masyarakat. Thinking again dapat dilakukan dengan me-review kembali apakah kebijakan, strategi, dan program yang sedang berjalan sudah tepat dan mampu memenuhi kebutuhan jamaah haji. Dan Thinking across dapat diaplikasikan dengan belajar dari pengalaman negara lain yang juga mengatur penyelenggaraan ibadah haji.
\end{abstract}

Kata Kunci: Dynamic Governance, Profesionalisme, Manajemen Haji

\begin{abstract}
The purpose of this research is to contribute initiative ideas to improve the hajj management professionalism through dynamic governance. This research uses qualitative type with descriptive approach. The research results with concern to the culture and capability of the Ministry of Religious Affairs formulate that thinking ahead can be executed by analyzing and projecting what will be facing in 10 or 20 years into the future based on the tendency toward national and global change, political constellation, and socio-economic of the community. Thinking again can be done by reviewing again whether policies, strategies and programs that are running are appropriate and able to meet the needs of pilgrims. And Thinking across, can be applied by learning from the experiences of other countries that also regulates the organization of the Hajj.
\end{abstract}

Keywords: Dynamic Governance, Professionalism, Hajj Management

\section{PENDAHULUAN}

Haji merupakan salah satu bentuk ibadah yang memiliki makna multi aspek meliputi ritual, politik psikologis, dan sosial. Ibadah haji dikatakan sebagai aspek ritual karena ibadah Haji merupakan rukun Islam kelima yang wajib dilaksanakan oleh setiap Muslim yang memenuhi syarat (istitha'a) baik secara finansial, fisik, maupun mental. Haji adalah ibadah yang hanya wajib di lakukan sekali seumur hidup dan merupakan bentuk ritual tahunan yang dilaksanakan kaum Muslim sedunia dengan berkunjung dan melaksanakan kegiatan di beberapa tempat di Arab Saudi. Hal ini berbeda dengan ibadah umroh yang bisa dilaksanakan sewaktu-waktu. Ritualitas haji sarat akan makna dan pelajaran untuk manusia (Mulyati, 2011:64). Dalam aspek ritual tersebut, Ibadah haji merupakan hal pribadi bagi masing-masing Muslim. Atau dengan kata lain warga negara berhak menjalankan ibadah haji tanpa ada intervensi dari negara.

Namun dari aspek psikologi politik, negara bertanggung jawab atas pelaksanaan agenda keagamaan termasuk di dalamnya adalah penyelenggaraan ibadah haji. Dalam tugas pokok dan fungsinya Kementerian Agama Republik Indonesia sebagai penyelenggara ibadah haji terus berupaya memberikan layanan terbaik dalam penyelenggaraan haji. Sehingga secara psikologis warga negara yang beragama Islam akan mendapatkan ketenangan karena merasa segala kepentingan mengenai ibadah haji telah diatur dan dilayani oleh pemerintahnya. Hal ini sebagaimana dijelaskan oleh Sondang Siagian yang dikutip oleh Kusuma (2015:104) bahwa pemerintah memiliki dua fungsi yaitu fungsi pengaturan (regulatory function) dan fungsi pelayanan (service function).

Dari aspek sosial, animo masyarakat Indonesia terhadap ibadah haji begitu tinggi. Bahkan saat ini waiting list haji menjadi semakin panjang dan lama. Masyarakat beranggapan bahwa haji memberikan implikasi lebih kepada setiap individu dibandingkan dengan masyarakat yang belum pernah berhaji. Hal tersebut dapat dibuktikan dengan munculnya pandangan masyarakat bahwa setiap individu yang telah menunaikan ibadah haji akan mendapat tempat yang terhormat dan menjadi tokoh yang dihormati dalam masyarakat. Dengan demikian maka dapat dikatakan bahwa haji telah menjadi 
status sosial yang dikejar oleh masyarakat kebanyakan. Seperti yang dikemukakan Hinkel yang dikutip oleh Ritzel (2003:42) bahwa manusia sebagai subyek manusia bertindak untuk mencapai tujuan-tujuan tertentu. Sehingga tindakan manusia bukan dilakukan tanpa alasan tertentu.

Pengelolaan haji tidak luput dari berbagai permasalahan. Di tengah kondisi ketidakpastian dan ancaman krisis keuangan global, Pemerintah Indonesia melalui Kementerian Agama dihadapkan pada problematika penyelenggaraan ibadah haji yang terus terjadi setiap tahunnya. Problem tersebut muncul mengingat penyelenggaraan ibadah haji tidak hanya dilakukan secara sepihak oleh pemerintah Indonesia, melainkan juga melibatkan banyak instansi baik di dalam negeri maupun di Arab Saudi. Problematika tersebut terkait dengan manajemen penyelenggaraan yang melipiti beberapa aspek seperti administrasi kelembagaaan, pengelolaaan keuangan, peningkatan sarana dan prasarana dalam memberikan pelayanan kepada jamaah haji. Bahkan baru-baru ini muncul masalah lain mengenai pemalsuan identitas jamaah haji asal Indonesia yang menggunakan passport Filipina. Akibatnya para jamaah haji illegal tersebut tertahan di imigrasi Filipina. Tentu ini adalah hal yang sangat memalukan. Hal-hal tersebut pada dasarnya adalah dampak sistemik dari perubahan yang cepat dan tidak terantisipasi akibat ketidakpastian global. Sebagai implikasinya pemerintah dituntut untuk mengambil langkah-langkah strategis karena tidak ada jaminan bahwa suatu kebijakan atau program yang sedang dijalankan oleh pemerintah saat ini dapat diimplementasikan sesuai dengan yang telah direncanakan atau nantinya kebijakan tersebut dapat berlanjut dalam jangka waktu yang lebih lama.

Pengelolaan haji juga tidak dapat dipisahkan dari alur birokrasi yang ada pada penyelenggara negara, dalam hal ini adalah Kementerian Agama. Birokrasi pada dasarnya adalah alat pemerintah yang bekerja untuk kepentingan masyarakat secara komprehensif. Dengan demikian maka tugas birokrasi adalah merealisasikan setiap kebijakan pemerintah demi kepentingan masyarakat. Namun sebagimana kita ketahui bahwa secara umum birokrasi di Indonesia masih lambat dan berbelit. Hal itulah yang seringkali dikeluhkan oleh masyarakat. Sehingga ketika mendengar istilah birokrasi maka pikiran masyarakat akan terasosiasikan pada suatu hal yang rumit dan tidak sederhana. Said (2012:40) mengemukakan bahwa secara internasional, reputasi birokrasi kita buruk. Banyak korupsi, tidak jelas tataran standarnya, tidak efisien, terlalu lemah dalam sistem pelayanan yang kaku dan jauh dari modern, tergantung dari orang seorang. Aturan terserah orangnya, bukan orangnya terserah aturan. Oleh karena itu dibutuhkan suatu perubahan nyata dalam upaya memperbaiki manajemen penyelenggaraan ibadah haji.

Membumikan Dynamic Governance adalah salah satu upaya untuk meminimalisir problematika tersebut. Dynamic Governance merupakan suatu konsep untuk tetap kompetitif dalam persaingan dunia yang mengalami percepatan globalisasi dan kemajuan teknologi. Konsep dasar dalam Dynamic Governance adalah mengkombinasikan budaya dan kapabilitas untuk berpikir ke depan (thinking ahead), berpikir lagi (thinking again), dan berpikir lintas batas (thinking across) guna menghasilkan suatu perubahan nyata kea rah yang lebih baik. Penulis berpandangan bahwa jika Dynamic Governance diterapkan secara konsekuen, maka akan turut mempengaruhi peningkatan kualitas pemberian pelayanan ibadah haji. Berdasar pemaparan latar belakang di atas maka penulis berketetapan untuk secara lebih dalam menggali, mendeskripsikan, dan menganalisis urgensi dari membumikan Dynamic Governance dalam meningkatkan profesionalisme manajemen penyelenggaraan haji di Indonesia.

Kajian ini akan mengeksplorasi bagaimana suatu dinamika dapat diciptakan dalam suatu kebijakan atau program yang dihasilkan institusi pemerintahan khususnya Kementerian Agama. Eksplorasi tersebut akan menggambarkan bagaimana budaya kelembagaan yang kuat dipadukan dengan kapabilitas dalam menciptakan suatu program atau kebijakan akan menghasilkan perubahan positif untuk meningkatkan profesionalisme manajemen penyelenggaraan haji.

\section{METODE}

Dalam penelitian ini jenis penelitian yang digunakan adalah kualitatif dengan pendekatan analisis deskriptif. Penelitian ini bertujuan untuk mendeskripsikan dan menganalisis urgensi membumikan Dynamic Governance dalam meningkatkan profesionalisme manajemen penyelenggaraan ibadah haji. Alasan penulis menggunakan penelitian deskriptif adalah agar hasil dari penelitian dapat dideskripsikan dan digambarkan dalam kalimat yang sistematis, faktual dan akurat mengenai fakta-fakta dan hubungan antar fenomena. Moleong (2000:6) menyatakan bahwa metode kualitatif adalah prosedur penelitian yang menghasilkan data deskriptif berupa kata-kata atau lisan dari orang dan perilaku yang dapat diamati. Jadi pendekatan ini diarahkan pada latar belakang objek secara keseluruhan. Paradigma kualitatif disebut pendekatan konstruktivis atau naturalistik, pendekatan interpretatif, atau postpositivist atau perspektif post-modern (Cresswell, 1998:4). Teknik pengumpulan data dilakukan melalui analisis dokumen terkait penyelenggaraan ibadah haji di Indonesia. Metode analis data yang digunakan dalam 
tulisan ini adalah metode Interaktif Miles dan Huberman yang terdiri dari empat tahap yaitu: pengumpulan data, reduksi data, penajian data dan penarikan kesimpulan (Miles dan Huberman, 1998:12).

\section{HASIL DAN PEMBAHASAN}

\section{Budaya + Kapabilitas = Perubahan}

Penyelenggaraan ibadah haji adalah bentuk kegiatan pelayanan publik yang dilakukan oleh pemerintah melalui Kementerian Agama setiap tahunnya. Dari tahun ke tahun jumlah jamaah haji Indonesia relatif terus bertambah. Di satu sisi, meningkatnya jumlah jamaah haji Indonesia ini dianggap sebagi hal yang menggembirakan, karena hal tersebut mengindikasikan bahwa kesadaran keagamaan masyarakat telah berbanding lurus dengan meningkatnya kemampuan ekonomi ummat. Ini juga dapat diartikan bahwa Muslim di Indonesia yang telah masuk dalam kategori mampu secara ekonomi tak lagi hanya berorientasi mengejar kepuasan dunia, namun juga memperhatikan peningkatan aspek religius dalam diri mereka. Namun di sisi lain, penyelenggaraan haji di Indonesia selalu menyisakan persoalan terutama tekait dengan manajemen pengelolaannya.

Hal tersebut diindikasikan dengan selalu munculnya ketidakpuasan jamaah calon haji terhadap manajemen penyelenggaraan haji dan pelayanan yang dilaksanakan oleh Kemenag. Kementerian Agama melalui berbagai inovasi dan penyempurnaan telah melakukan upaya-upaya peningkatan baik dari aspek manajerial, sumber daya manusia, serta berbagai pola operasional. Oleh karena itu penulis berpendapat bahwa Dynamic Governance sangatlah urgen untuk diterapkan dalam upaya meningkatkan profesionalisme manajemen penyelenggaraan haji. Yang perlu diingat bahwa munculnya Dynamic Governance tidak terjadi secara kebetulan, tetapi merupakan hasil dari niat dan ambisi yang disengaja melalui sebuah kepemimpinan untuk struktur sosial yang diinginkan untuk mencapai tujuan nasional. Dynamic Governance mencerminkan upaya pemimpin yang dengan sengaja untuk membentuk masa depan mereka. Konsep dasar Dynamic Governance adalah mengkombinasikan budaya dengan kapabilitas sehingga menghasilkan perubahan ke arah yang lebih baik.

Sebagaimana telah disebutkan di atas bahwa Dynamic Governance merupakan kombinasi antara budaya dengan kapabilitas yang menghasilkan perubahan. Budaya menunjukkan keyakinan dan nilainilai kelompok tertentu yang dibagi atau dimiliki bersama, sehingga dapat dianggap sebagai akumulasi pelajaran bersama dari masyarakat tertentu berdasarkan sejarah pengalaman bersama. Peraturan dan struktur pemerintahan adalah pilihan yang dibuat oleh masyarakat dan mencerminkan nilai-nilai dan kepercayaan dari para pemimpinnya. Kepercayaan pemimpin membentuk aturan, norma-norma informal dan mekanisme penegakan yang dilembagakan. Diakui atau tidak, pandangan masyarakat terhadap kinerja Kemenag adalah lambat dan berbelit. Seolah-olah hal yang lambat dan berbelit adalah budaya dalam Kemenag itu sendiri.

Stigma dari masyarakat itu mau tidak mau harus menjadi perhatian dari Kemenag. Stigma bahwa birokrasi di Kemenag itu lambat dan berbelit harus diubah. Belum lagi dengan selentingan adanya pungli-pungli yang membuat image birokrasi terutama Kemenag semakin buruk. Memang dalam Undang-Undang No. 17 tahun 1999 tentang penyelenggaraan ibadah haji telah disebutkan bahwa peningkatan pembinaan, pelayanan, dan perlindungan terhadap jamaah haji diupayakan melalui penyempurnaan sistem dan manajemen penyelenggaraan ibadah haji. Namun peningkatan yang diinginkan masyarakat bukan hanya dalam tataran konsep, melainkan pada tataran implementasinya di lapangan. Sehingga budaya lambat dan berbelit-belit dalam birokrasi Kemenag bisa menjadi cepat, efektif, dan efisien.

Selanjutnya Kemenag juga harus meningkatkan kapabilitas dalam manajemen penyelenggaraan haji. Salah satu cara yang telah ditempuh adalah dengan menggandeng perguruan tinggi sebagai mitra pemerintah. Tujuannya adalah untuk memperoleh basis kajian secara ilmiah dan independen, tanpa intervensi atau tendensi tertentu. Oleh karena itu sejak tahun 2012, Kemenag melalui Dirjen Penyelenggaran Haji dan Umroh yang dipimpin oleh Anggito Abimanyu telah menggandeng Jurusan Manajemen Dakwah (MD) Universitas Islam Negeri Sunan Kalijaga Yogyakarta untuk membuka Program Studi Manajemen Haji dan Umroh. Pada poin inilah Jurusan MD UIN Sunan Kalijaga mengambil peran aktif dengan memasukkan manajemen haji sebagai bagian dari keilmuan yang digeluti. Kerjasama ini diharapkan mampu memberikan sumbangsih berupa pemikiran-pemikiran kritis terkait peningkatan manajemen penyelenggaraan haji.

Upaya merubah stigma masyarakat yang memandang bahwa budaya birokrasi di Kemenag itu lambat dan berbelit dengan birokrasi Kemenag yang cepat, efektif, dan efisien dikombinasikan dengan peningkatan kapabilitas Kemenag melalui kerjasama dengan perguruan tinggi seperti Jurusan MD UIN Sunan Kalijaga untuk memperoleh basis kajian secara ilmiah dan independen akan menghasilkan perubahan yaitu manajemen penyelengggaraan haji yang lebih professional. Selain itu, dalam konsep Dynamic Governance, seorang pemimpin juga harus think ahead, 
think again, dan think across. Apabila digambarkan dalam alur flowchart, sistem kerja Dynamic Governance adalah sebagai berikut:

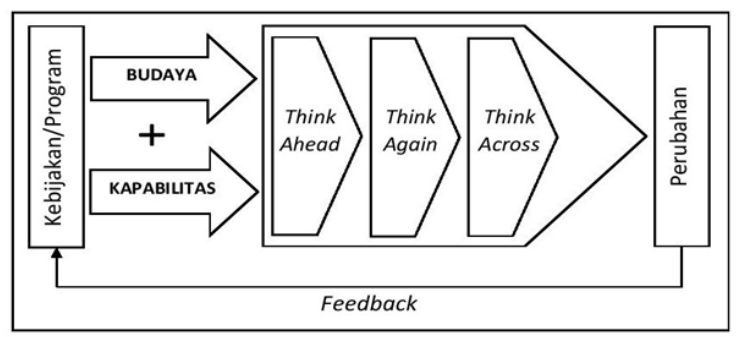

Gambar 1. Sistem Kerja Dynamic Governance

\section{Think Ahead, Think Again, dan Think Across Secara Berkelanjutan}

Haji tidak hanya mencakup persoalan agama, tapi juga wisata keagamaan dan ini terkait dengan bisnis, dimana ini juga berurusan dengan jamaah haji dalam jumlah yang massif, melibatkan telasi transnasional, pemerintah pusat dan daerah, penerbangan dan agen travel, unit pembimbing haji, katering dan hotel, dan lain sebagainya (Ichwan, 2008:126). Hal tersebut mengindikasikan bahwa haji adalah persoalan yang sangat kompleks.

Oleh karena itu dalam konsep Dynamic Governance, pemimpin harus berpikir secara cerdas dan taktis dengan mengartikulasikan ide-idenya. Berpikir ke depan (think ahead) adalah kemampuan untuk mengidentifikasi perkembangan lingkungan di masa depan, memahami implikasinya, dan mengidentifikasi strategi yang diperlukan untuk memanfaatkan peluangpeluang baru dan mencegah potensi ancaman. Maksud berpikir ke depan adalah untuk mendorong lembaga dalam menilai risiko strategi dan kebijakan saat ini, merefresh tujuan, dan konsep inisiatif kebijakan baru untuk mempersiapkan masa depan.

Dalam konteks ini, pada dasarnya pemerintah Arab Saudi sebenarnya sudah berupaya memperbaiki kualitas penyelenggaraan dan kuantitas daya tampung mereka, namun bagaimanapun juga upaya mereka ada batasnya. Kita jangan hanya merisaukan itu, tetapi kita justru harus lebih memperbaiki manajemen haji kita. Kita selayaknya harus men-setup ulang kebutuhan penyelenggaran haji kita berdasarkan situasi dan kondisi negara tujuan, yaitu Arab Saudi. Dengan demikian paling tidak kita telah menghindarkan kemungkinan buruk yang terjadi menimpa jamaah haji Indonesia, seperti halnya musibah yang pernah terjadi beberapa waktu lalu di Mina. Oleh karena itu kita harus berpikir ke depan dengan melihat kondisi riil di Arab Saudi sebagai acuan, untuk kemudian menyesuaikan manajemen penyelenggaraan haji kita dengan kondisi di Arab Saudi.
Berpikir lagi (think again) adalah kemampuan untuk menghadapi realitas saat ini berkaitan dengan strategi, kebijakan dan program yang sudah ada, dan kemudian mendesain ulang dari hasil umpan balik untuk mencapai kualitas yang lebih baik. Berpikir lagi dilakukan dengan cara membandingkan kinerja kebijakan dan program yang telah berjalan dengan maksud dan hasil yang diinginkan. Analisis berdasarkan pada data aktual, informasi, pengukuran dan umpan balik untuk isuisu permukaan dan masalah yang menghambat kinerja untuk menjadi lebih lebih baik lalu merumuskan kebijakan atau program tertentu untuk mencari solusi dalam meningkatkan kinerjanya. Berpikir lagi dapat dipicu oleh keberhasilan ataupun kegagalan yang yang dialami dari kebijakan atau program sebelumnya untuk merangsang memikirkan kembali kebijakan yang lebih baik. Dalam konteks penyelenggaraan haji, berpikir lagi adalah melihat apakah kebijakan-kebijakan sebelumnya sudah berjalan sesuai dengan yang diinginkan dan kemudian bagaimanakah untuk memperbaiki kebijakankebijakan yang telah berjalan tersebut.

Disini penulis melihat bahwa sudah saatnya pemerintah mengintegrasikan teknologi secara lebih jauh dalam manajemen penyelenggaraan haji kita. Misalkan saja sebagaimana kita ketahui bahwa jamaah haji kita menggunakan gelang sebagai identitas pengenal. Namun gelang tersebut hanyalah gelang yang data-datanya hanya dapat dilihat secara manual. Maka di sinilah teknologi harus masuk lebih dalam. Penyelenggara haji dapat mengintegrasikan sistem satelit atau global positioning system (GPS) ke dalam gelang tersebut. Manfaatnya adalah penyelenggara dapat mendeteksi dimanapun keberadaan jamaah haji Indonesia, kapanpun dan dimanapun. Apabila terjadi sesuatu maka penyelenggara akan segera mengetahui dan segera melakukan tindakan penanggulangan. Sehingga dengan demikian kemungkinan buruk yang menimpa jamaah haji Indonesia seperti yang terjadi beberapa waktu lalu dapat dihindarkan atau paling tidak diminimalisir.

Adapun berpikir lintas batas (think across) adalah kemampuan untuk melintasi batas-batas tradisional untuk belajar dari pengalaman orang lain yang kemudian hasilnya dapat diadopsi atau diadaptasi sesuai dengan kebutuhan. Dalam hal ini, memang benar bahwa manajemen penyelengaraan haji di Indonesia masih dianggap yang terbaik di dunia. Alasannya adalah dengan kondisi geografis Indonesia yang luas serta beranekaragam budaya dan karakter penduduknya, Indonesia mampu memberangkatkan jamaah haji dalam jumlah besar. Namun kondisi tersebut tidak boleh membuat Kemenag menjadi berpuas diri lantas menjadi lengah. Tidak ada ruginya jika Indonesia mengadopsi atau mengadaptasikan model manajemen 
penyelenggaraan haji dari negara lain pada aspek-aspek tertentu.

Seperti misalnya pada aspek akomodasi penginapan, Indonesia dapat mengadopsi dari negara Malaysia yang teah melakukannya dengan lebih baik. Dalam aspek penginapan, Indonesia selalu memilih durasi yang berlaku hanya satu tahun atau satu musim haji, sementara Malaysia selalu memilih durasi antara tiga sampai lima tahun. Dampaknya adalah jika Indonesia selalu memilih durasi satu tahun, maka setiap tahunnya penyelenggara akan disibukkan dengan proses pengurusan penginapan. Jika indonesia mengadopsi cara yang dilakukan oleh Malaysia, maka Indonesia tidak harus mengurus pengadaan penginapan setiap tahun, sehingga beban penyenggara akan berkurang dan konsentrasi penyelenggara dapat dialihkan kepada aspek lain yang membutuhkan perhatian tinggi. Dan sebagai implikasinya konsentrasi penyelenggara ibadah haji akan lebih terfokus yang pada nantinya juga akan mendukung peningkatan profesionalime manajemen penyelenggaran haji.

\section{PENUTUP}

\section{Simpulan}

Ibadah haji merupakan ibadah yang memiliki makna multi aspek meliputi ritual, politik psikologis, dan sosial. Dikatakan sebagai aspek ritual karena ibadah Haji merupakan rukun Islam kelima yang wajib dilaksanakan oleh setiap Muslim yang memenuhi syarat istitha'a. Dari aspek psikologi politik, negara bertanggung jawab atas pelaksanaan agenda keagamaan termasuk penyelenggaraan ibadah haji. Dari aspek sosial, masyarakat beranggapan bahwa haji memberikan implikasi lebih kepada setiap individu dibandingkan dengan orang yang belum pernah berhaji. Namun penyelenggaraan haji selalu menyisakan persoalan terutama tekait dengan manajemen pengelolaannya. Oleh karena itu Dynamic Governance sangatlah urgen untuk diterapkan dalam upaya meningkatkan profesionalisme manajemen penyelenggaraan haji.

Dynamic Governance merupakan kombinasi antara budaya dengan kapabilitas yang menghasilkan perubahan. Daer aspek budaya, Diakui atau tidak bahwa lambat dan berbeli-belit merupakan gambaran masyarakat terhadap budaya kinerja Kemenag secara umum. Stigma bahwa birokrasi di Kemenag itu lambat dan berbelit harus diubah menjadi cepat, efektif, dan efisien. Sedangkan dari aspek kapabilitas, salah satu cara yang dapat ditempuh Kemenag untuk meningkatkannya adalah dengan menggandeng perguruan tinggi sebagai mitra pemerintah untuk memperoleh basis kajian secara ilmiah dan independen, seperti menggandeng Jurusan Manajemen Dakwah Universitas Islam Negeri Sunan
Kalijaga Yogyakarta dalam membuka konsentrasi Manajemen Haji dan Umroh. Dari sini akan didapatkan kajian-kajian ilmiah tentang manajemen penyelenggaraan haji.

Dalam konsep Dynamic Governance, pemimpin harus berpikir berpikir ke depan (think ahead). Dalam artian kita harus berpikir ke depan dengan melihat kondisi di Arab Saudi sebagai acuan, untuk kemudian menyesuaikan manajemen penyelenggaraan haji kita dengan kondisi mereka. Kemudian berpikir lagi (think again). Caranya adalah dengan mengintegrasikan teknologi secara lebih jauh dalam manajemen penyelenggaraan haji kita, seperti mengintegrasikan sistem satelit atau global positioning system (GPS) ke dalam gelang jamaah haji. Dan pemimpin juga harus berpikir lintas batas (think across), dengan mengadopsi atau mengadaptasikan model manajemen penyelenggaraan haji dari negara lain pada aspek-aspek tertentu. Misalkan mengadopsi Malaysia pada aspek akomodasi penginapan

\section{DAFTAR PUSTAKA}

Bhatta, G. (2006). International Dictionary of Public Management and Governance. New York: M.E. Sharpe.

Boon, S. N. dan Chen, G. (2007). Dynamic Governance: Embedding Cultures, Cappabilities, and Change in Singapore. Singapore: World Scientific Publishing.

Carino, L. V. (2000). "The Concept of Governance". Dalam Eastern Regional Organization for Public Administration, From Government to Governance: Reflection on the 1999 World Conference on Governance. Quezon City: EROPA Press.

Creswell, J. W. (1998). Qualitative Inquiry and Research Design. New York: Sage Publications.

Dwiyanto, A. (2010). Manajemen Pelayanan Publik: Peduli, Inklusif, dan Kolaboratif. Yogyakarta: Gadjah Mada University Press.

Hayat, B. (2011). "Profesionalisme Manajemen dalam Penyelenggaraan Ibadah Haji”. Dalam Dinamika dan Perspektif Haji Indonesia. Jakarta: Dirjen Penyelenggaraan Haji dan Umrah Kemenag RI.

Ichwan, M. N. (2008). "Governing Hajj: Politics of Islamic Pilgrimage Services in Indonesia Prior to Reformasi”. Dalam Al-Jami'ah: Journal of Islamic Studies Vol. 46 No. 1.

Kusuma, B. M. A dan Octastefani, T. (2015). "Implementasi Program Jaminan Pelayanan Kesehatan Masyarakat Banyuwangi (JPKMB) Dalam Mewujudkan Pelayanan Kesehatan Primer Bagi Seluruh Lapisan Masyarakat". Dalam The Indonesian Journal of Public Administration Vol. 2 No. 1.

Miles, M. B. dan Huberman, A. M. (1998). Qualitative Data Analysis: A Source Book of New Methods. London: Sage Publication. 
Moleong, L. J. (2000). Metode Penelitian Kualitatif. Bandung: Remaja Rosdakarya.

Mulyati, S. (2011). "Haji, Sebuah Arena Spiritualitas". Dalam Dinamika dan Perspektif Haji Indonesia. Jakarta: Dirjen Penyelenggaraan Haji dan Umrah Kemenag RI.

Ritzel, G. (2003). Sosiologi Ilmu Pengetahuan Berparadigma Ganda. Terj. Alimandan. Jakarta: Raja Grafindo Persada.
Said, M. M. (2012). Birokrasi di Negara Birokratis: Makna, Masalah, dan Dekonstruksi Birokrasi Indonesia. Malang: UMM Press.

Sinambela, L. P. et al. (2010). Reformasi Pelayanan Publik: Teori, Kebijakan, dan Implementasi. Jakarta: Bumi Aksara.

Thoha, M. (2012). Birokrasi Pemerintah dan Kekuasaan di Indonesia. Yogyakarta: Thafa Media.

World Bank. (2000). World Bank Report: Governance Matters. Washington: World Bank. 